Article

\title{
Who Criticizes the Clergy in Contemporary Lithuania? A Sociohistorical Analysis of Anticlericalism
}

\author{
Milda Alisauskiene ${ }^{1, *(D)}$ and Apolonijus Zilys ${ }^{2}$ \\ 1 Department of Political Science, Vytautas Magnus University, 44248 Kaunas, Lithuania \\ 2 Department of Sociology, Vytautas Magnus University, 44248 Kaunas, Lithuania; apolonijus.zilys@vdu.lt \\ * Correspondence: milda.alisauskiene@vdu.lt
}

Citation: Alisauskiene, Milda, and Apolonijus Zilys. 2022. Who Criticizes the Clergy in Contemporary Lithuania? A Sociohistorical Analysis of Anticlericalism. Religions 13: 4. https://doi.org/10.3390/rel 13010004

Academic Editors: Bulcsu Bognár and Marta Trzebiatowska

Received: 13 September 2021 Accepted: 3 December 2021

Published: 21 December 2021

Publisher's Note: MDPI stays neutral with regard to jurisdictional claims in published maps and institutional affiliations.

Copyright: (C) 2021 by the authors. Licensee MDPI, Basel, Switzerland. This article is an open access article distributed under the terms and conditions of the Creative Commons Attribution (CC BY) license (https:// creativecommons.org/licenses/by/ $4.0 /)$.

\begin{abstract}
This paper analyzes the phenomenon of anticlericalism in contemporary Lithuania, applying a sociohistorical approach. It starts with a discussion on the problem of criticism of religion and anticlericalism in contemporary societies, and particularly Lithuania. The empirical part of the paper provides a statistical data analysis of two surveys, conducted in 2012 and 2018. The secondary data analysis showed that age and place of residence of Roman Catholics in Lithuania were statistically meaningful factors for the formation of anticlerical stances. Younger respondents expressed more critical stances towards the clergy, while respondents living in large cities of the country had more relaxed stances towards clergy than those living in small towns and rural areas. Living in a proximity to a Roman Catholic church in rural areas determined the prevalent anticlerical attitudes among the Lithuanian population.
\end{abstract}

Keywords: anticlericalism; criticism of religion; atheism; freethinking; religion-state relations

\section{Introduction}

The increasing role of religion in the public sphere of contemporary society is one of the outcomes of religious change in the context of globalization and migration. As various social research scholars have observed, religion in contemporary society has been becoming more individualized and privatized, but at the same time more public (Casanova 1994). Although these generalizations on the role of religion in public seem to be questioned, the post-socialist central and eastern European societies have undergone socio-political transformations that have had a considerable impact on their religious lives, and a period of religious revival brought an increase in religious beliefs and practices in many societies (Norris and Inglehart 2004; Müller 2008). More recently, however, trends of emergence of religious individualism have been observed in central and eastern European societies, along with a diversification of religious lives that made generalizations difficult. A factor that remains common to most of these societies is the existence and hegemony of national churches and their hegemony. The public spheres in central and eastern Europe are usually dominated by national churches, leaving little space for manifestation of religious diversity and non-religious worldviews. Investigating these religious and non-religious alternatives allows us to understand the trajectories of change in society.

Belonging to a religious community does not necessarily lead to religious beliefs and practices, as critical attitudes towards religion can also be observed inside of religions. Processes of diversification within religious communities allow us to identify both liberal and conservative approaches towards moral and religious values.

The sociologist of religion Jörg Stolz et al. (2016, p. 135) observed the return of criticism of religion in contemporary societies. They noted that although this criticism is usually linked with Enlightenment thinkers, the works of recent critics of religion including Richard Dawkins, Sam Harris, and Christopher Hitchens have been bestselling books. Basing their work on empirical data, Stolz et al. discovered a wide range of forms of criticism of religion from public debates on the conflict between religion and science and the contribution of 
religion to war. Stolz et al. (2016) suggested that the return of criticism of religion became the social reality of contemporary Western societies with the emergence of the movement of freethinkers.

While movements promoting non-religious worldviews are becoming more popular in Western societies, in many central and eastern European countries, the hegemony of national churches continues, although criticism of religion finds its own way. Among its manifestations one might find anticlericalism, i.e., hostility to the power and status of priests or ministers (Hinnells 1997, p. 215). In this paper, we will analyze the phenomenon of anticlericalism in contemporary Lithuania. Firstly, we will discuss the sociohistorical context of anticlericalism in Lithuania with an overview of history of Roman Catholicism and the role of the Roman Catholic Church in public life. Secondly, we will provide secondary data analysis on public attitudes towards the clergy and their development during the period 2012-2018. This period might be seen as illustrating the third decade after the socio-political transformations took place in contemporary Lithuania. Sociologically and demographically, this period is marked by the visibility of a new cohort born in the independent state, who become active in the public life and add to the civil society. Politically and economically, this period is marked with strengthening relations with the European Union, its impact on the country's politics and economics.

\section{The Roman Catholic Church and Anticlericalism in Lithuania: A Sociohistorical Approach}

The history of criticism of religion and anticlericalism may be traced back to Lithuania, which was then part of the Russian Empire, around the end of the nineteenth century. The end of the nineteenth century in Lithuania was defined by the Russian Empire's waning influence and a softer religious politics, particularly in relation to the Roman Catholic Church's role in the country. The establishment of religious freedom and a movement involving the construction of Roman Catholic Church buildings followed these processes. The Tsarist regime's softening policies paved the way for a variety of social activities, both religious and non-religious (Streikus 2006, p. 391). Attempts to form a Lithuanian freethinking organization were seen on both sides of the Atlantic beginning in 1895. Dr. Jonas Šliūpas created Laisvamaniu etinès kultūros draugija (The Ethical Society of Freethinkers) in the Lithuanian town of Šiauliai in 1923 with other like-minded persons; the group was legally registered the following year. This organization aspired to bring together all Lithuanian citizens who have severed ties with any religious denomination or Church. Its other goals included introducing a comparative study of the history of religions, ethics, and the teaching of evolution in public schools, as well as civil marriage, sterilization, and cremation, as well as the establishment of freethinker cemeteries. After the introduction of a new constitution in 1938, the goal of allowing civil marriage was ultimately realized. The group had 55 divisions around Lithuania, and it began publishing the newspaper Laisvoji mintis (Freethought) in 1933, as well as establishing book shops and graves for freethinkers (Ališauskienè 2020).

Before and during the First Republic of Lithuania, the freethought movement aimed to question the dominant Roman Catholic faith's role in Lithuanian identity, the relationship between the Roman Catholic Church and the Republic of Lithuania, and the importance placed on scientific knowledge, its application in everyday life, and rationalization. The freethought movement aimed to question the dominant Roman Catholic faith's role in Lithuanian identity, the relationship between the Roman Catholic Church and the Republic of Lithuania, and the value placed on scientific knowledge, its application in everyday life, and rationalization before and during the First Republic of Lithuania. Even though pre-World War II freethought and atheist concepts and manifestations were later used by Soviet authorities to legitimize atheism in the country, freethought organizations were dissolved and their leaders, such as Dr. Jonas Šliūpas, left the country.

Scientific atheism was the former Soviet Union's official state ideology, which was implemented after the conquest of Lithuania. Scientific atheism, the Communist Party's 
intellectual viewpoint, posited a moral code of conduct as the ultimate purpose of human existence and created a variety of atheistic rites and ceremonies that imitated religious ones and thus aimed at displacement and control of religion (Bruce 2003; Froese 2004) Religious organizations, particularly the predominant Roman Catholic Church, had their activities restricted; the clergy could not conduct their customary duties, and a significant portion of the Church's property was nationalized. The Soviet authorities in charge of ideological work largely embraced the activities and social achievements of Lithuanian freethinkers prior to the occupation, however the activities of freethinkers were considered by the Soviet authorities to be those that "did not internalize the Marx-Leninist methodology" (Mikuckas 1985, pp. 144-59). Anti-religious and anti-clerical views were extensively promoted by Soviet propaganda, resulting in the privatization of religion (Streikus 2003, 2004).

In current Lithuanian public life and the country's religious landscape, freethought and atheism are neglected phenomena. Atheists have developed a virtual Facebook group, however they do not believe that institutionalization is necessary. Studies of atheism in Lithuania showed that contemporary atheism includes criticism of the Roman Catholic Church's hegemonic position, anticlericalism, and patriarchy. In Lithuania, atheism, like other religions and worldviews, is regarded as a private rather than a public affair. In the media, atheism is also stereotyped as being associated with communism and the Soviet era (Ališauskiene 2020). Despite the public's hostility to atheism and freethought, critical attitudes toward religion and, in particular, the clergy's activities, find support in other layers of society.

During the 2011 population and housing census, the majority of the Lithuanian population $(77.2 \%)$ considered themselves Roman Catholic, the largest religious minority was the Russian Orthodox community (4.1\%), and other minority religions were much smaller in membership (Ambrozaitiene et al. 2013, p. 152). The tendency of the majority of population to declare belonging to the Roman Catholic Church was influenced by factors other than religious ones. The beliefs and practices of the majority of Roman Catholics were far from the ideal way of living Catholicism (Laumenskaitè 2015; Kuznecovienè et al. 2016; Žiliukaite et al. 2016). In Lithuania, despite the short-term religious revival after the collapse of the Soviet Union, the impact of religion on people's everyday lives was relative. Younger people expressed more individualistic and liberal attitudes than older people (particularly those raised during Soviet times), who expressed more conservative values and were inclined towards collectivism (Žiliukaitè et al. 2016). The Lithuanian population's religious beliefs and practices have little impact on public attitudes towards the Roman Catholic Church. The institution of the Church, despite tendencies of religious individualism, continues to be an authority on moral issues in the society (Kuznecoviene et al. 2016).

The proportion of the Lithuanian population considering themselves non-believers, non-belonging, and not declaring religious belonging remained approximately the same (16\%) between the two national housing and population censuses in 2001 and 2011 (Ambrozaitiene e The majority of the non-believing part of the Lithuanian population lived in urban areas.

The tendency of the majority of Lithuanians to belong to the Roman Catholic Church might be explained from various perspectives. The need to belong to the majority religious community leads to considerations about identity formation processes and relations between various aspects of one's identity-gender, ethnicity, nationality. The sociologist Hervieu-Leger (2000) saw individuals' identity formation through the lenses of the relations between religion and social memory existing in the certain society. Anthropologist Schröder (2012) emphasized the relations between religion and ethnical/national identity, particularly the historical role of religion in the nation-making processes that led to a situation in which the majority of society expresses belonging to a religious organization. Political scientist Anna Grzymała-Busse (2015) analyzed several Roman Catholic societies, providing empirically tested theoretical considerations that the role of dominant religion in society was linked to its position towards the authoritarian regime the country has experienced. In countries where the Roman Catholic Church supported authoritarian regimes, for instance Spain, its position in the current state receives little support from 
society. In countries where the Roman Catholic Church resisted an authoritarian regime, meanwhile, such as Poland, its position in the society has reached enormous authority. Following this idea, the idea of a religious organization having symbolic capital might be applied. Sociologist Grace Davie (2008) suggested using the term "vicarious religion" for analysis of societies with dominant religion, large numbers of adherents, and low level of religiosity, referring particularly to Scandinavian societies. There is no one explanation concerning the tendency for the majority of Lithuanians to consider themselves Roman Catholic but express a low level of religiosity. All the theoretical considerations mentioned above might be considered, and the country's historical and social context should also be taken into account.

The role of the Roman Catholic Church in Lithuanian public life since the 1990s has been marked by a desire to return to the pre-Second World War position, balancing during this period between becoming the state religion and building new relations with state and society (Vardys 1997; Vardys and Sedaitis 1997). Although the 1992 Constitution states that there is no state religion in Lithuania, the actual relationship between the Roman Catholic Church and the state in fact resembles more this kind of relations. After Lithuania's declaration of independence, the Church returned from underground activities and some members of its clergy dedicated themselves to the reestablishment of the state, participating successfully in the parliamentary elections. After 1996, the Church declared withdrawal from participation in political life. These activities continued implicitly, however, especially in political debates on moral and Church property issues. Since 2000, the Church has formed a ring of satellite non-governmental organizations that have become its public voice. These organizations have promoted traditional family values and a pro-life agenda in the political arena, receiving support from conservative right-wing political powers and criticism from progressive liberal organizations and politicians (Ališauskienè and Kuznecovienè 2012). Public discussions ongoing since 2000 have questioned the position of the Church, and in 2011, the position of the Church defining family was rejected by The Constitutional Court of the Republic of Lithuania (2011). It is evident that the population has ambiguous attitudes towards the position of the Church. However, the coherence between the religious and political elite supports Church hegemony, it continues to be the authority on moral issues, and Roman Catholicism holds a monopoly as the system of meaning (Schröder 2012).

The hegemony of the Roman Catholic Church in Lithuanian society constructs a place for the emergence of criticism of religion, particularly Roman Catholicism, with a focus on priests, or clergy more broadly. Although only a few cases of child abuse by clergy have been reported in Lithuania, the global concern about child abuse in the Roman Catholic Church has received media attention and the Church has been criticized. These features of the religious field of Lithuania serve as conditions for the rise of criticism of religion in society, expressed firstly through criticism of the clergy and its role in politics. As anticlericalism is inseparable from religion, it is worth considering that those who support it would be dissimilar to the ones who are religious-women, elderly people, and living in the rural areas.

Women are considered to be more religious than men and seen as the carriers of tradition and the main agents of religious socialization in traditional societies dominated by Christianity (Trzebiatowska and Bruce 2016). This position has been challenged by women's emancipation, secularization, and the process of moral pluralism, factors influenced by modernization and individualization in post-industrial society. Lithuanian social attitudes towards family and women remain patriarchal, although the changes within family life have been affected by the aforementioned cultural and social factors. Although the aforementioned cultural and social elements have influenced developments within family life, Lithuanian social attitudes about family and women remain patriarchal. Soviet gender equality policy that was forcefully implemented in the country, though there were some shifts in the 1990s, such as more traditional ideas toward gender roles in family life, this did not change the trend toward greater gender equality in public life. Nonetheless, in Lithuania, traditional gender roles within the family are still observed (Kraniauskas 2009). 
Social research on the relationship between religiosity and age demonstrates, in contrast, that older people are more religious than other age groups; elderly people are also more conservative in their moral attitudes (Žiliukaite et al. 2016, p. 183). Anticlerical attitudes might therefore be expected to be more popular among younger generations.

The relationship between religion and place of living is frequently discussed in the literature addressing the phenomenon of religious diversity (Stringer 2013). The formation of modern cities and megacities, migration, and globalization have formed conditions for religious diversity to emerge, in comparison to the small towns and rural areas where social control ensures the existence of religious monopoly. Following this line of thinking, anticlericalism might be found in both large cities and rural territories, but the initial context influenced by diverse religious views might serve as a more favorable foundation for anticlericalism to emerge.

In the following part of this paper, we will provide a secondary data analysis of the attitudes of the Lithuanian Roman Catholic population towards the involvement of clergy in public life and politics, which we see as one of the core elements constituting anticlericalism.

\section{Secondary Data Analysis Methodology}

In this paper, we present analysis of data from two national surveys as a representation of short-term time-snapshots to identify whether there have been any changes in public attitudes towards the clergy's public engagement in Lithuania. The first survey was implemented by Vytautas Magnus University within the research project "The Peculiarities of the Process of Secularization in Lithuania", and data were collected as part of the National Lithuanian barometer in 2012. The second survey includes the Lithuanian sub-sample data of the International Social Survey Program of 2018, which was also implemented by Vytautas Magnus University. Representative samples were used for both surveys, but it is worth mentioning that the sampling techniques had some slight differences. The data for the 1008 respondents were collected from individuals aged 15-74 and living in Lithuania in 2012, while applying random route sampling. For the 2018 survey, 1057 individuals aged at least 18 years old (with no upper age limit) and living in Lithuania at the time were selected from households chosen using stratified multistage sampling. The age limits were restricted for the further data analysis, only the data of the 18-74-year-old population from both datasets were used in the paper. Although the main aim is to provide an overview of whether there were any changes in Roman Catholics' public attitudes towards the clergy in Lithuania during the six-year period, the further longitudinal analysis involved testing three hypotheses which included some of the respondents' socio-demographic features:

1. Female Roman Catholics would be less critical towards the public engagement of clergy.

2. The elder and senior Roman Catholic generation would be less critical and the younger and middle generations would be more critical towards the public engagement of clergy.

3. The Roman Catholic population from rural areas would be less critical towards the public engagement of clergy.

These characteristics of both surveys are presented in Table 1, which includes only those respondents who identified themselves as Roman Catholics in the corresponding surveys. In 2012, a total of 95.7\% (774) were Roman Catholics and the rest, 4.3\% (33), identified with other religious groups, while in 2018, 93.9\% (922) were Roman Catholics and the rest, $6.1 \%$ (59), were identified with other religious groups. Those who did not identify with any religious group, refused to answer the question, or gave other answers of missing values were omitted from the calculations. 
Table 1. Selected socio-demographic features of Roman Catholics in Lithuania (in 2012 and 2018).

\begin{tabular}{|c|c|c|c|c|}
\hline \multirow{2}{*}{ Socio-Demographic Characteristics } & \multicolumn{2}{|c|}{2012} & \multicolumn{2}{|c|}{2018} \\
\hline & $\mathbf{N}$ & $\%$ & $\mathbf{N}$ & $\%$ \\
\hline \multicolumn{5}{|l|}{ Gender } \\
\hline Male & 329 & 45.5 & 334 & 39.0 \\
\hline Female & 394 & 54.5 & 522 & 61.0 \\
\hline \multicolumn{5}{|l|}{ Generation (Age Cohort) $^{\dagger}$} \\
\hline Younger $(>1984)$ & 106 & 14.7 & 249 & 29.1 \\
\hline Middle (1965-1984) & 214 & 29.6 & 274 & 32.0 \\
\hline Elder $(<1965)$ & 403 & 55.7 & 333 & 38.9 \\
\hline \multicolumn{5}{|l|}{ Vicinity $\S$} \\
\hline Large urban areas & 265 & 36.7 & 332 & 38.8 \\
\hline Urban areas & 198 & 27.4 & 228 & 26.6 \\
\hline Rural areas & 260 & 36.0 & 296 & 34.6 \\
\hline
\end{tabular}

${ }^{\dagger}$ The average age of Roman Catholics in Lithuania was 48.6 years with standard deviation of 16.5 in the 2012 survey, and the average age for 2018 was 46 years with standard deviation of 17.4. $\$$ Large urban areas consist of the five biggest Lithuanian cities, and urban or rural areas were classified by the official categorization of Statistics Lithuania (excluding large urban areas).

The empirical basis of benevolent public attitudes towards the clergy's public engagement is represented by three items-"Priests should be allowed to participate in politics, or have an opportunity to be elected to parliament, municipal councils, etc."; "Priests should actively participate in the setting up of law and legal acts"; "Religious leaders should not try to influence the government decision" - which were measured on a 5-point Likert scale. However, the 5-point Likert scales were recoded as a 3-point scale, which was used for the further statistical analysis. A variety of scales can be constructed regarding attempts to conceptualize the public engagement of clergy, but these scales are good indicators of how the Lithuanian Catholic population approve or disapprove of the clergy's public engagement in certain political domains such as the legislative, judicial, and executive government branches. It was decided not to use a combined scale of all three scales as all the items measure different intensity of public attitudes towards the clergy's public engagement. ${ }^{1}$

\section{Secondary Data Analysis}

The general trend is that the Lithuanian Roman Catholic population has a more critical view towards the more active role of priests in the legislative, judicial, and executive government branches (see Table 2). Quite a large majority (70\%) of the Catholic population in Lithuania disagree with priests' active role in general elections or law making, and a significant majority (more than $45 \%$ ) still feel that religious leaders should not participate in government decisions. It is important to note that the data also demonstrate a slight shift in the attitudes towards the clergy in Lithuania within the six-year period. The relationship between the timeline and public attitudes towards priests participating in politics and general elections is statistically significant $\left(\chi^{2}(2, \mathrm{~N}=1579)=7.79, p<0.01\right)$, and it can be traced that disagreement decreased by $6 \%$, while agreement increased only by $3.6 \%$ during the same six-year period. There is a statistically significant dependency between the shortterm period and being less critical of the clergy's active role in the judicial process among the Catholic population $\left(\chi^{2}(2, \mathrm{~N}=1579)=9.67, p<0.01\right)$, and general disagreement with this position decreased by $5 \%$. A contingency table analysis did not reveal any significant shifts in general public sentiment that religious leaders should not influence government decisions. To sum up, a small increase appeared in deeper public endorsement for more significant engagement of the clergy among the Catholic population in certain public areas such as general elections or legislative propositions, but the analyzed time-period indicates a very weak effect on both attitudes, as Cramer's V coefficient varies between 0.08 and 0.07 . 
Table 2. Anti-clergy sentiments shift during a short-term period (2012-2018) in Lithuania.

\begin{tabular}{|c|c|c|c|c|c|}
\hline Year & $\begin{array}{c}\mathrm{N} \\
(\mathbf{1 0 0} \%)\end{array}$ & Disagree & $\begin{array}{l}\text { Neither Agree } \\
\text { nor Disagree }\end{array}$ & Agree & $\begin{array}{c}\chi^{2}(\mathrm{df}) \\
\text { Cramer's V }\end{array}$ \\
\hline \multicolumn{6}{|c|}{$\begin{array}{l}\text { Priests should be allowed to participate in politics, or have an opportunity to be elected to } \\
\text { parliament, municipal councils, etc. }\end{array}$} \\
\hline 2012 & 723 & $76.3 \%$ & $7.5 \%$ & $16.2 \%$ & \multirow{2}{*}{$\begin{array}{c}\chi^{2}=7.79(2)^{*} \\
\mathrm{~V}=0.07^{*}\end{array}$} \\
\hline 2018 & 856 & $70.2 \%$ & $10.2 \%$ & $19.6 \%$ & \\
\hline \multicolumn{6}{|c|}{ Priests should actively participate in the setting up of law and legal acts. } \\
\hline 2012 & 723 & $73.6 \%$ & $6.9 \%$ & $19.5 \%$ & \multirow{2}{*}{$\begin{array}{l}\chi^{2}=9.67(2)^{* *} \\
V=0.078^{* *}\end{array}$} \\
\hline 2018 & 856 & $68.6 \%$ & $11.3 \%$ & $20.1 \%$ & \\
\hline \multicolumn{6}{|c|}{ Religious leaders should not try to influence government decisions. } \\
\hline 2012 & 723 & $37.6 \%$ & $9.4 \%$ & $53.0 \%$ & \multirow{2}{*}{$\begin{array}{l}\chi^{2}=3.36(2)^{n s} \\
V=0.046^{n s}\end{array}$} \\
\hline 2018 & 856 & $40.5 \%$ & $11.0 \%$ & $48.5 \%$ & \\
\hline
\end{tabular}

A series of contingency tables (see Table 3) were produced to assess whether there are any different positions regarding the public engagement of clergy among Catholic men and women in each time-period. Although minor differences between gender categories can be found in all of them, there is no statistically significant dependency between gender and anti-clergy sentiment in each year's samples. In this instance, the hypothesis that Catholic women would be less critical towards public engagement of the clergy than Catholic men could be rejected.

Table 3. Anti-clergy sentiments among Roman Catholic men and women in Lithuania.

\begin{tabular}{|c|c|c|c|c|c|c|}
\hline Year & Gender & $\begin{array}{c}\mathrm{N} \\
(\mathbf{1 0 0} \%)\end{array}$ & Disagree & $\begin{array}{l}\text { Neither Agree } \\
\text { nor Disagree }\end{array}$ & Agree & $\begin{array}{c}\chi^{2}(\mathrm{df}) \\
\text { Cramer's } \mathrm{V}\end{array}$ \\
\hline \multicolumn{7}{|c|}{$\begin{array}{l}\text { Priests should be allowed to participate in politics, or have an opportunity to be elected to } \\
\text { parliament, municipal councils, etc. }\end{array}$} \\
\hline \multirow{2}{*}{2012} & Male & 329 & $75.1 \%$ & $7.0 \%$ & $17.9 \%$ & \multirow{2}{*}{$\begin{array}{c}\chi^{2}=1.46(2)^{n s} \\
V=0.034^{n s}\end{array}$} \\
\hline & Female & 394 & $77.4 \%$ & $7.9 \%$ & $14.7 \%$ & \\
\hline \multirow{2}{*}{2018} & Male & 334 & $72.2 \%$ & $8.4 \%$ & $19.5 \%$ & \multirow{2}{*}{$\begin{array}{c}\chi^{2}=2.01(2)^{n s} \\
V=0.048^{n s}\end{array}$} \\
\hline & Female & 522 & $69.0 \%$ & $11.3 \%$ & $19.7 \%$ & \\
\hline \multicolumn{7}{|c|}{ Priests should actively participate in the setting up of law and legal acts. } \\
\hline \multirow{2}{*}{2012} & Male & 329 & $72.0 \%$ & $6.7 \%$ & $21.3 \%$ & \multirow{2}{*}{$\begin{array}{c}\chi^{2}=1.22(2)^{n s} \\
V=0.041^{n s}\end{array}$} \\
\hline & Female & 394 & $74.9 \%$ & $7.1 \%$ & $18.0 \%$ & \\
\hline \multirow{2}{*}{2018} & Male & 334 & $68.3 \%$ & $10.8 \%$ & $21.0 \%$ & \multirow{2}{*}{$\begin{array}{c}\chi^{2}=0.36(2)^{n s} \\
V=0.02^{n s}\end{array}$} \\
\hline & Female & 522 & $68.8 \%$ & $11.7 \%$ & $19.5 \%$ & \\
\hline \multicolumn{7}{|c|}{ Religious leaders should not try to influence government decisions. } \\
\hline \multirow{2}{*}{2012} & Male & 329 & $36.8 \%$ & $8.8 \%$ & $54.4 \%$ & \multirow{2}{*}{$\begin{array}{c}\chi^{2}=0.57(2)^{\mathrm{ns}} \\
\mathrm{V}=0.028^{\mathrm{ns}}\end{array}$} \\
\hline & Female & 394 & $38.3 \%$ & $9.9 \%$ & $51.8 \%$ & \\
\hline \multirow{2}{*}{2018} & Male & 334 & $41.0 \%$ & $10.5 \%$ & $48.5 \%$ & \multirow{2}{*}{$\begin{array}{l}\chi^{2}=0.157(2)^{n s} \\
V=0.014^{n s}\end{array}$} \\
\hline & Female & 522 & $40.2 \%$ & $11.3 \%$ & $48.5 \%$ & \\
\hline
\end{tabular}

${ }^{* * *} p<0.001 ;{ }^{* *} p<0.01 ;^{* *} p<0.05 ;{ }^{\text {ns }} p>0.05$.

Although anti-clergy sentiments do not depend on gender, the age cohort is a meaningful factor which explains some differences of public opinion in all three anti-clergy sentiment scales and in both surveys (see Table 4). Firstly, the older Catholic generations are less critical of priests' role in politics and participation in general elections, and this anti-clergy sentiment depended on age in $2012\left(\chi^{2}(4, \mathrm{~N}=723)=10.26, p<0.05\right)$ and 2018 $\left(\chi^{2}(4, N=856)=34.5, p<0.001\right)$ surveys. The younger and middle generations tend to agree rather more with the anti-clergy positions, that the clergy should not participate in the government's decision-making processes, and that priests should not be involved 
in the law-making process, compared to the elder and senior generations. However, the dependency between age cohort and both anti-clergy sentiments is statistically significant only for $2018\left(\chi^{2}(4, \mathrm{~N}=856)=26.61, p<0.001\right.$, and $\left(\chi^{2}(4, \mathrm{~N}=856)=16.59, p<0.001\right)$ sub-sample, and insignificant for 2012. However, there is a peculiar data point visible in the contingency tables, showing that the generation most critical of priests' role is not the youngest, but the middle one. The age of the Roman Catholic population in Lithuania has a statistically significant and small effect on all three anti-clergy sentiments, as $\phi$ coefficients spread within an interval of 0.119 and 0.201 . In conclusion, the hypothesis that the elder Catholic generation is less critical than the younger and middle generations could be accepted, and the general trend shows that seniors are the most relaxed of all generations regarding anti-clergy sentiments. However, this tendency just indicates relative anti-clergy sentiments, and a general and persistent trend shows that the Roman Catholic population most of all retains a more secular opinion across generations.

Table 4. Anti-clergy sentiments among different Roman Catholics' age cohorts in Lithuania.

\begin{tabular}{|c|c|c|c|c|c|c|}
\hline Year & Age Cohorts & $\begin{array}{c}\mathrm{N} \\
(100 \%)\end{array}$ & Disagree & $\begin{array}{l}\text { Neither } \\
\text { Agree nor } \\
\text { Disagree }\end{array}$ & Agree & $\begin{array}{c}\chi^{2}(\mathrm{df}) \\
\text { Cramer's V }\end{array}$ \\
\hline \multicolumn{7}{|c|}{$\begin{array}{l}\text { Priests should be allowed to participate in politics, or have an opportunity to be elected to } \\
\text { parliament, municipal councils, etc. }\end{array}$} \\
\hline \multirow{3}{*}{2012} & Younger (>1984) & 106 & $76.4 \%$ & $10.4 \%$ & $13.2 \%$ & \multirow{3}{*}{$\begin{array}{c}\chi^{2}=10.26(4) * \\
\phi=0.119 *\end{array}$} \\
\hline & Middle (1965-1984) & 214 & $82.7 \%$ & $6.1 \%$ & $11.2 \%$ & \\
\hline & Elder $(<1965)$ & 403 & $73.0 \%$ & $7.4 \%$ & $19.6 \%$ & \\
\hline \multirow{3}{*}{2018} & Younger (>1984) & 249 & $68.7 \%$ & $18.5 \%$ & $12.9 \%$ & \multirow{3}{*}{$\begin{array}{c}\chi^{2}=34.5(4)^{* * * *} \\
\phi=0.201\end{array}$} \\
\hline & Middle (1965-1984) & 274 & $73.7 \%$ & $5.1 \%$ & $21.2 \%$ & \\
\hline & Elder $(<1965)$ & 333 & $68.5 \%$ & $8.1 \%$ & $23.4 \%$ & \\
\hline \multicolumn{7}{|c|}{ Priests should actively participate in the setting up of law and legal acts. } \\
\hline \multirow{3}{*}{2012} & Younger (>1984) & 106 & $76.4 \%$ & $9.4 \%$ & $14.2 \%$ & \multirow{3}{*}{$\begin{array}{c}\chi^{2}=8.32(4)^{\mathrm{ns}} \\
\phi=0.107^{\mathrm{ns}}\end{array}$} \\
\hline & Middle (1965-1984) & 214 & $77.6 \%$ & $7.0 \%$ & $15.4 \%$ & \\
\hline & Elder $(<1965)$ & 403 & $70.7 \%$ & $6.2 \%$ & $23.1 \%$ & \\
\hline \multirow{3}{*}{2018} & Younger (>1984) & 249 & $68.7 \%$ & $18.5 \%$ & $12.9 \%$ & \multirow{3}{*}{$\begin{array}{c}\chi^{2}=26.61(4)^{* * *} \\
\phi=0.176^{* * *}\end{array}$} \\
\hline & Middle (1965-1984) & 274 & $71.2 \%$ & $7.7 \%$ & $21.2 \%$ & \\
\hline & Elder $(<1965)$ & 333 & $66.4 \%$ & $9.0 \%$ & $24.6 \%$ & \\
\hline \multicolumn{7}{|c|}{ Religious leaders should not try to influence government decisions. } \\
\hline \multirow{3}{*}{2012} & Younger (>1984) & 106 & $38.7 \%$ & $15.1 \%$ & $46.2 \%$ & \multirow{3}{*}{$\begin{array}{l}\chi^{2}=7.95(4)^{n s} \\
V=0.105^{n s}\end{array}$} \\
\hline & Middle (1965-1984) & 214 & $33.2 \%$ & $9.3 \%$ & $57.5 \%$ & \\
\hline & Elder $(<1965)$ & 403 & $39.7 \%$ & $7.9 \%$ & $52.4 \%$ & \\
\hline \multirow{3}{*}{2018} & Younger (>1984) & 249 & $37.8 \%$ & $17.7 \%$ & $44.6 \%$ & \multirow{3}{*}{$\begin{array}{c}\chi^{2}=16.59(4)^{* *} \\
\phi=0.139^{* *}\end{array}$} \\
\hline & Middle (1965-1984) & 274 & $42.0 \%$ & $9.1 \%$ & $48.9 \%$ & \\
\hline & Elder $(<1965)$ & 333 & $41.4 \%$ & $7.5 \%$ & $51.1 \%$ & \\
\hline
\end{tabular}

Table 5 illustrates the variety of Roman Catholic anti-clergy stances across the three types of localities in Lithuania, and we can form the general conclusion that these attitudes were dependent on residential area. Nonetheless, there are some differences in the three anti-clergy scales because not all three items used are dependent on the location of Roman Catholics. The relationship between the attitudes towards priests participating in politics and the individual's place of residence was statistically significant $\left(\chi^{2}(4, N=856)=20.11\right.$, $p<0.001)$ in the 2018 survey; Catholics from smaller urban areas were more critical than those who lived in large urban or rural areas. A similar pattern manifested in 2018, because the view that priests should actively participate in the formation of law and legal acts is dependent on locality $\left(\chi^{2}(4, \mathrm{~N}=856)=17.04, p<0.01\right)$ : Roman Catholics from urban areas held a more critical view than individuals from large urban or rural areas. Such a tendency is also evident with the third anti-clergy stance, that urban dwellers hold a more critical 
view than large urban or rural dwellers if religious leaders actively involve themselves in government decision making, but the dependency is statistically significant only for 2012 $\left(\chi^{2}(4, N=723)=27.8, p<0.001\right)$ period. Lastly, the place of residence of Roman Catholics has a small effect on disapproval for the public engagement of more significant clergy (at least in 2018), as the $\phi$ coefficient varies between 0.140 and 0.160 . To conclude, it is possible to accept the premises of the hypothesis that the Catholic population from rural areas is less critical towards public engagement of clergy than the urban population; however, Catholics from smaller urban areas are even more critical than those from large urban areas.

Table 5. Roman Catholics' anti-clergy sentiments in different Lithuanian localities.

\begin{tabular}{|c|c|c|c|c|c|c|}
\hline Year & Vicinity & $\begin{array}{c}N \\
(100 \%)\end{array}$ & Disagree & $\begin{array}{l}\text { Neither } \\
\text { Agree nor } \\
\text { Disagree }\end{array}$ & Agree & $\begin{array}{c}\chi^{2}(\mathrm{df}) \\
\phi\end{array}$ \\
\hline \multicolumn{7}{|c|}{$\begin{array}{l}\text { Priests should be allowed to participate in politics, or have an opportunity to be elected to } \\
\text { parliament, municipal councils, etc. }\end{array}$} \\
\hline \multirow{3}{*}{2012} & Large urban areas & 265 & $78.9 \%$ & $7.9 \%$ & $13.2 \%$ & \multirow{3}{*}{$\begin{array}{c}\chi^{2}=6.95(4)^{\mathrm{ns}} \\
\phi=0.098^{\mathrm{ns}}\end{array}$} \\
\hline & Urban areas & 198 & $77.3 \%$ & $8.6 \%$ & $14.1 \%$ & \\
\hline & Rural areas & 260 & $73.1 \%$ & $6.2 \%$ & $20.8 \%$ & \\
\hline \multirow{3}{*}{2018} & Large urban areas & 332 & $64.5 \%$ & $13.0 \%$ & $22.6 \%$ & \multirow{3}{*}{$\begin{array}{l}\chi^{2}=20.11(4)^{* * *} \\
\phi=0.153^{* * *}\end{array}$} \\
\hline & Urban areas & 228 & $81.1 \%$ & $7.0 \%$ & $11.8 \%$ & \\
\hline & Rural areas & 296 & $68.2 \%$ & $9.5 \%$ & $22.3 \%$ & \\
\hline \multicolumn{7}{|c|}{ Priests should actively participate in the setting up of law and legal acts. } \\
\hline \multirow{3}{*}{2012} & Large urban areas & 265 & $71.7 \%$ & $8.7 \%$ & $19.6 \%$ & \multirow{3}{*}{$\begin{array}{c}\chi^{2}=5.65(4)^{\mathrm{ns}} \\
\phi=0.088^{\mathrm{ns}}\end{array}$} \\
\hline & Urban areas & 198 & $77.3 \%$ & $7.1 \%$ & $15.7 \%$ & \\
\hline & Rural areas & 260 & $72.7 \%$ & $5.0 \%$ & $22.3 \%$ & \\
\hline \multirow{3}{*}{2018} & Large urban areas & 332 & $62.3 \%$ & $13.6 \%$ & $24.1 \%$ & \multirow{3}{*}{$\begin{array}{l}\chi^{2}=17.04(4)^{* *} \\
\phi=0.141^{* *}\end{array}$} \\
\hline & Urban areas & 228 & $78.5 \%$ & $8.8 \%$ & $12.7 \%$ & \\
\hline & Rural areas & 296 & $67.9 \%$ & $10.8 \%$ & $21.3 \%$ & \\
\hline \multicolumn{7}{|c|}{ Religious leaders should not try to influence the government decisions. } \\
\hline \multirow{3}{*}{2012} & Large urban areas & 265 & $48.7 \%$ & $10.6 \%$ & $40.8 \%$ & \multirow{3}{*}{$\begin{array}{c}\chi^{2}=27.80(4)^{* * *} \\
\phi=0.196^{* * *}\end{array}$} \\
\hline & Urban areas & 198 & $27.8 \%$ & $9.6 \%$ & $62.6 \%$ & \\
\hline & Rural areas & 260 & $33.8 \%$ & $8.1 \%$ & $58.1 \%$ & \\
\hline \multirow{3}{*}{2018} & Large urban areas & 332 & $39.8 \%$ & $13.3 \%$ & $47.0 \%$ & \multirow{3}{*}{$\begin{array}{c}\chi^{2}=7.15(4)^{\mathrm{ns}} \\
\phi=0.106^{\mathrm{ns}}\end{array}$} \\
\hline & Urban areas & 228 & $45.2 \%$ & $7.0 \%$ & $47.8 \%$ & \\
\hline & Rural areas & 296 & $37.8 \%$ & $11.5 \%$ & $50.7 \%$ & \\
\hline
\end{tabular}

In the following analysis, we use the pooled data of 2012 and 2018 as a joint dataset with additional categorical covariance-year. A series of binomial logistic regression models (see Table 6) were performed in order to explore whether period and one of the three sociodemographic characteristics of Roman Catholics could predict anti-clergy sentiment. The anti-clergy sentiment scales were recoded into three dummy variables, which should indicate an anti-clergy position or other position. For the purposes of further analysis, a three-point scale was transformed into binary categories-0 (Agree and Neither agree nor disagree) and 1 (Disagree)—and the last item (Religious leaders should not try to influence the government decisions) was reversed to represent the anti-clergy sentiment. Each model represents an anti-clergy item with binary responses in the table below. There are three statistically significant factors (out of year, gender, age cohort, and locality) in the regression models of anti-clerical attitude towards priests' participation in elections $\left(\chi^{2}(6, \mathrm{~N}=1579)=29.04, p<0.001\right)$ and participation in law making $\left(\chi^{2}(6, N=1579)=29.47, p<0.001\right)$, and only one factor for the model, which represents the view that religious leaders should not be involved in government decision making $\left(\chi^{2}(6, \mathrm{~N}=1579)=21.99, p<0.01\right)^{2}$ 
Table 6. Anti-clergy sentiments by gender, age cohort, locality, and year among Roman Catholic population in Lithuania $(\mathrm{N}=1579)$.

\begin{tabular}{|c|c|c|c|c|c|c|c|c|c|c|}
\hline \multirow[t]{2}{*}{ Predictor } & & \multicolumn{3}{|c|}{ Model $1^{\dagger}$} & \multicolumn{3}{|c|}{ Model $2^{\dagger}$} & \multicolumn{3}{|c|}{ Model $3^{\dagger}$} \\
\hline & & B & S.E. & $\operatorname{Exp}(\beta)$ & B & S.E. & $\operatorname{Exp}(\beta)$ & B & S.E. & $\operatorname{Exp}(\beta)$ \\
\hline Constant & & 1.047 & 0.170 & $2.849^{\mathrm{ns}}$ & 0.856 & 0.167 & $2.354^{\mathrm{ns}}$ & -0.283 & 0.152 & $0.754^{\mathrm{ns}}$ \\
\hline Year $\S$ & 2018 & -0.334 & 0.118 & $0.716^{* *}$ & -0.282 & 0.115 & $0.754^{* *}$ & -0.147 & 0.104 & $0.864^{\mathrm{ns}}$ \\
\hline Gender $\S$ & Female & -0.039 & 0.116 & $0.962^{\mathrm{ns}}$ & 0.077 & 0.113 & $1.080^{\mathrm{ns}}$ & -0.046 & 0.103 & $0.955^{\mathrm{ns}}$ \\
\hline \multirow[t]{2}{*}{$\begin{array}{c}\text { Age } \\
\text { cohort } \$\end{array}$} & $\begin{array}{c}\text { Middle } \\
(1965-1984)\end{array}$ & 0.311 & 0.162 & $1.364 *$ & 0.099 & 0.158 & $1.104^{*}$ & 0.264 & 0.142 & $1.302^{\mathrm{ns}}$ \\
\hline & Elder $(<1965)$ & -0.097 & 0.147 & $0.908^{\mathrm{ns}}$ & -0.215 & 0.146 & $0.807^{\mathrm{ns}}$ & 0.180 & 0.134 & $1.198^{\mathrm{ns}}$ \\
\hline \multirow[t]{2}{*}{ Locality $\S$} & Urban areas & 0.471 & 0.151 & $1.602 * *$ & 0.598 & 0.146 & $1.818^{* * *}$ & 0.411 & 0.128 & $1.508^{* *}$ \\
\hline & Rural areas & -0.008 & 0.131 & $0.992^{\mathrm{ns}}$ & 0.193 & 0.128 & $1.213^{\mathrm{ns}}$ & 0.380 & 0.119 & $1.462^{\mathrm{ns}}$ \\
\hline \multicolumn{2}{|c|}{$-2 L L$} & \multicolumn{3}{|c|}{1812.24} & \multicolumn{3}{|c|}{1877.75} & \multicolumn{3}{|c|}{2166.78} \\
\hline \multicolumn{2}{|c|}{$\chi^{2}(\mathrm{df})$} & \multicolumn{3}{|c|}{$29.04(6)^{* * *}$} & \multicolumn{3}{|c|}{$29.47(6) * * *$} & \multicolumn{3}{|c|}{$21.99(6) * *$} \\
\hline \multirow{2}{*}{\multicolumn{2}{|c|}{$\begin{array}{l}\text { Hosmer-Lemeshow } \chi^{2}(\mathrm{df}) \text { test } \\
\text { Classification accuracy }\end{array}$}} & \multicolumn{3}{|c|}{$8.74(8), p>0.05$} & \multicolumn{3}{|c|}{$7.43(8), p>0.05$} & \multicolumn{3}{|c|}{$13.62(8), p>0.05$} \\
\hline & & \multicolumn{3}{|c|}{$73 \%$} & \multicolumn{3}{|c|}{$70.9 \%$} & \multicolumn{3}{|c|}{$56.1 \%$} \\
\hline \multicolumn{2}{|c|}{ Nagelkerke $\mathrm{R}^{2}$} & \multicolumn{3}{|c|}{0.04} & \multicolumn{3}{|c|}{0.03} & \multicolumn{3}{|c|}{0.02} \\
\hline
\end{tabular}

+ Model 1 tests item 'Priests should be inclined to participate in politics, or have an opportunity to be elected in Parliament, municipal councils, etc.', Model 2 tests item 'Priests should actively participate in the setting up of law and legal acts', and Model 3 tests item 'Religious leaders should influence the decisions of government' (reversed statement). § reference categories: '2012' for year, 'male' for gender, 'younger (>1984)' for age cohort, and 'large urban areas' for locality variables. ${ }^{* * *} p<0.001$; ${ }^{* *} p<0.01{ }^{*} p<0.05$; ${ }^{\text {ns }} p>0.05$.

Breaking down significant logistic regression models (of participation in elections, law making, and influencing the government decisions) after controlling for other factors, contrary to the general hypothesis, gender is not a statistically significant predictor of those anti-clergy views among Catholics in Lithuania $(\exp (\beta)=0.962, p>0.05$ for Model 1; $\exp (\beta)=0.113, p>0.05$ for Model 2; and $\exp (\beta)=0.955, p>0.05$ for Model 3), and this result reiterates the previously discussed results of dependency testing between gender and anti-clergy sentiments. However, age cohort of middle generation in comparison with the youngest cohort (as a reference category) is a significant predictor for two anti-clergy stances in regard to participation in elections $(\exp (\beta)=1.364, p<0.05)$ and law making $(\exp (\beta)=1.104, p<0.05)$, while there is no statistical association comparing the youngest and oldest generations $(\exp (\beta)=0.908, p>0.05$ for Model $1 ; \exp (\beta)=0.807, p>0.05)$. Additionally, the age is not a significant factor which can be associated with a skeptic view on clergy's influence on government decisions. This conclusion provides a more nuanced insight that prevalent anti-clergy views (based on participation in election and law making) are held by middle generations compared to the rest age cohorts. Individuals living in the vicinity of urban areas in comparison with those who are living in the large urban areas (as a reference category) differ in their anti-clergy views: the urban dwellers lean to express a more negative view on clergy's participation in elections $(\exp (\beta)=1.602$, $p<0.001)$, law making $(\exp (\beta)=1.818, p<0.001)$, and influencing government decisions $(\exp (\beta)=1.508, p<0.001)$. Lastly, it can be concluded that some changes in anti-clergy stances are time-dependent. Roman Catholics in 2018 held more relaxed anti-clergy stance compared to 2012 period: it is significant for two views, that clergy should not participate in elections $(\exp (\beta)=0.716, p<0.01)$ or law making $(\exp (\beta)=0.754, p<0.01)$.

Aligning regression analysis results with those of dependency testing, it is possible to conclude that still gender is not associated, while some generational, urban-rural, and even time differences are associated with anti-clergy stances. It is important to note that rurality-urbanity and generational divisions do not neatly predict anti-clergy sentiment among Roman Catholics in Lithuania. As it was previously shown that Roman Catholics from urban (compared to large urban and rural) areas and of the middle (compared to the youngest and oldest) generation tend to be the most critical towards public engagement. 


\section{Conclusions}

A variety of factors influence the role of religion in the public sphere of contemporary Western societies, including historically constructed religion and state relations, trends of migration, and globalization. The criticism of religion is a growing tendency in various Western societies. Religion and state relations in the societies of central and eastern European countries are usually marked by the dominance of the national churches. Lithuania is one of these countries in which the public sphere is marked by the hegemony of Roman Catholic Church, which has historically marginalized secular worldviews. The history of freethought and atheism in the country was manifested with anticlericalism and antagonism towards the binding relationship between religion and state. Although most Lithuanians declare belonging to the Roman Catholic Church, most also express anticlerical attitudes. Generally speaking, Roman Catholics in Lithuania hold quite a secular view, because the majority of the Catholic population tend to have a critical view of priests' active role in politics, political elections, and law making, and a slightly relaxed, but even more critical view about religious leaders' involvement in government decision making. Certain minor shifts of public opinion occurred during the short period between 2012 and 2018 in Lithuania: approaches to priests' active role in politics, political elections, and law making softened slightly during these six years, but these sentiments still have strong support from the Catholic population.

Although social research has shown that women are more religious than men in Christian-dominated societies, this would not lead to the immediate conclusion that anticlerical stances would be more prevalent among men. Our research shows that gender alone is not a factor which influences anticlerical attitudes during the 2012-2018 period. The hypothesis that Catholic women would be less critical towards public engagement of clergy than their male counterparts could therefore be rejected.

The relationship between religion and age, particularly the tendency that elderly people seem to be more religious, does not also lead to the conclusion that they are not critical towards the clergy. Based on the Lithuanian data, we can partly accept the hypothesis that the elder Catholic generation would be less critical than younger ones (vs. youngest and middle generations). Data provide an insight that the middle generation of Roman Catholics in the Lithuanian society in comparison with the youngest and oldest cohorts hold more of an anti-clergy stance with regard to participation in elections and law making. Summarizing, the age cohort has a small effect on anti-clergy views, such as priests' active role in politics, political elections, and law making, and there is a general tendency that just the youngest generation of Catholics tend to be more critical towards public engagement of the clergy than the oldest one.

The locality of Roman Catholics as a predictor for anti-clergy sentiments is an interesting case as it was for age cohort factor. The hypothesis that the Catholic population from rural areas would be less critical towards public engagement of clergy than the urban population could be rejected because the data showed the mixed results. Place of residence as a predictor is a significant one (and has a small effect), yet there is a reverse tendency that Catholics from large urban areas will be more likely to hold relaxed anti-clergy sentiment than Catholics from other areas, especially in the case of attitudes towards priests' active role in politics, political elections, and law making. The findings regarding the factor of people's place of residence on the attitudes towards the clergy mean that living in large urban areas and experiencing religious diversity in everyday life led to more relaxed attitudes towards clergy participation in politics; however, experiences of Roman Catholic hegemony in other urban areas determined more critical attitudes towards the clergy.

This research contributed to a more in-depth understanding of the processes of social change in the field of religion in contemporary Lithuania, manifested in critical attitudes towards the clergy's involvement in politics and more broadly about the role of religion in public. These research findings allow us to conclude that criticism of religion in the shape of anticlericalism is prevalent among Roman Catholics in Lithuania, and thus illustrates 
the trends of religious individualism in the context of increasing dominance of the Roman Catholic Church in the public sphere of the country in the last decade.

Author Contributions: Conceptualization, M.A.; methodology, M.A. and A.Z.; formal analysis, A.Z.; funding acquisition, M.A. All authors have read and agreed to the published version of the manuscript.

Funding: This research received funding from the Research Council of Lithuania under Grant No. P-MIP-17-367. The 2012 survey data used in this paper was gathered with the help of funding received from the Research Council of Lithuania under the Grant No. VAT-22/2010.

Institutional Review Board Statement: Not applicable.

Informed Consent Statement: Not applicable.

Data Availability Statement: Not applicable.

Conflicts of Interest: The authors declare no conflict of interest.

\section{Notes}

$1 \quad$ All three scales were tested for the internal consistency and unidimensionality, but the fit was poor. Cronbach's alpha (0.568) and KMO measure (0.51) after principal component analysis were low. "Religious leaders should not try to influence the government decision" scale was reversed and tested along other two scales.

2 Model fit and Hosmer-Lemeshow tests of all models exhibit an acceptable level of data fit. The classification accuracy was similar for Model 1 and Model 2, while Model 3 showed sligtly worse accuracy. Nagelkerke $\mathrm{R}^{2}$ for all models is extremely low, but concerning the low values of Nagelkerke $\mathrm{R}^{2}$ for both statistically significant models, it is important to note that the main focus of regression modeling in this paper is not to indicate how much dependent variables could be explained by the models, but to answer which of the used socio-demographic variables could be identified as predictors for anti-clergy sentiment. Moreover, it would be quite naïve to think that anti-clergy sentiments could be explained only by gender, age, and vicinity, and to expect high values of Nagelkerke $R^{2}$.

\section{References}

Ališauskienè, Milda. 2020. The Social History of Irreligion in Lithuania (from the 19th century to the present): Between Marginalization, Monopoly and Disregard? In Freethought and Atheism in Central and Eastern Europe. Edited by Tomáś Bubík, Atko Remmel and David Václavík. London and New York: Routledge, pp. 155-76.

Ališauskienė, Milda, and Jolanta Kuznecovienè. 2012. Kataliku bažnyčios vaidmuo viešajame Lietuvos gyvenime: Dalyvavimo formu kaita (1990-2010). Filosofija Sociologija 23: 102-10.

Ambrozaitienè, Dalia, Rasa Balandienė, Natalja Nikiforova, Eglè Norušienė, Edita Onichovska, Vanda Vaitekūnienė, Julija Važnevičiūee, and Asta Vildžiūnienè. 2013. Lietuvos Respublikos 2011 Metų Gyventoju ir Būstų Surašymo Rezultatai. Vilnius: Lietuvos Statistikos Departamentas, p. 152.

Bruce, Steve. 2003. Politics and Religion. Cambridge: Polity Press.

Casanova, José. 1994. Public Religions in the Modern World. Chicago: Chicago University Press.

Davie, Grace. 2008. From ‘Believing without belonging' to 'Vicarious Religion': Understanding the Patterns of Religion in Modern Europe. In The Role of Religion in Modern Societies. Edited by Detlef Pollack and Daniel Olson. New York: Routledge, pp. 165-76.

Froese, Paul. 2004. After Atheism: An Analysis of Religious Monopolies in the Post-Communist World. Sociology of Religion 65: 35. [CrossRef]

Grzymała-Busse, Anna. 2015. Nations under God: How Churches Use Their Moral Authority to Influence Policy. Princeton: Princeton University Press.

Hervieu-Leger, Daniele. 2000. Religion as a Chain of Memory. Cambridge: Polity Press.

Hinnells, John R. 1997. Dictionary of Religions. London: Penguin Books, p. 215.

Kraniauskas, Liutauras. 2009. Vyriškas ir moteriškas šeimos pasaulis: Struktūros poveikis ar tapatumo konstravimo strategija? In Lietuvos Šeima: Tarp Tradicijos ir Naujos Realybès. Edited by Vlada Stankūnienè and Aušra Maslauskaitè. Vilnius: Socialiniu tyrimu centras, pp. 169-219.

Kuznecovienè, Jolanta, Aušra Rutkienė, and Milda Ališauskienė. 2016. Religingumas ir/ar Dvasingumas Lietuvoje: Religijos Sociologijos Perspektyvos: Mokslo Studija. Kaunas: Pasaulio Lietuviụ Kultūros, Mokslo ir Švietimo Centras.

Laumenskaitė, Eglè Irena. 2015. Krikščioniškumas Kaip Socialiniu Laikysenu Veiksnys Totalitarinëje ir Posovietinèje Visuomenèje. Vilnius: Lietuviu Kataliku Mokslo Akademija.

Mikuckas, Pranas. 1985. Marksistinis ateizmas Lietuvoje iki Tarybu valdžios atkūrimo. In Ateizmas ir Religija Lietuvoje. Edited by Jonas Mačiulis. Vilnius: Mintis, pp. 144-59. 
Müller, Olaf. 2008. Religion in Central and Eastern Europe: Was There a Reawakening After the Breakdown of Communism? In The Role of Religion in Modern Times. Edited by Detlef Pollack and Daniel V. A. Olson. New York: Routledge, pp. 63-92.

Norris, Pippa, and Ronald Inglehart. 2004. Sacred and Secular. Religion and Politics Worldwide. Cambridge: Cambridge University Press.

Schröder, Ingo W. 2012. The Elusive Religious Field in Lithuania. In Religious Diversity in Post-Soviet Society: Ethnographies of Catholic Hegemony and the New Pluralism in Lithuania. Edited by Milda Ališauskienè and Ingo W. Schröder. Farnham: Ashgate, pp. 79-98.

Stolz, Jörg, Judith Könemann, Malory Schneuwly Purdie, Thomas Englberger, and Michael Kruggeler. 2016. (Un)Believing in Modern Society. Religion, Spirituality, and Religious-Secular Competition. Farnham: Ashgate, p. 135.

Streikus, Arūnas. 2003. Ateistinès propagandos pobūdis Lietuvoje 1975-1988 m. Genocidas ir Rezistencija 1: 7-21.

Streikus, Arūnas. 2004. Antireliginè propaganda Lietuvoje 1944-70 metais. Lietuvos Istorijos Studijos 14: 88-99.

Streikus, Arūnas. 2006. Religijos laisvès atgavimas ir kataliku akcijos. In Krikščionybès Lietuvoje Istorija. Edited by Vytautas Ališauskas. Vilnius: Aidai, p. 391.

Stringer, Martin D. 2013. Discourses on Religious Diversity. Exploration in an Urban Ecology. Surrey: Ashgate.

The Constitutional Court of the Republic of Lithuania. 2011. On the 3 June 2008 Resolution of the Seimas of the Republic of Lithuania on the Approval of the Provisions of the State Family Policy Concept with the Constitution of the Republic of Lithuania. Available online: https:/ / www.lrkt.lt/lt/teismo-aktai/paieska/135/ta159/content (accessed on 16 May 2020).

Trzebiatowska, Marta, and Steve Bruce. 2016. Why Are Women More Religious than Men? Oxford: Oxford University Press.

Vardys, Vytautas S. 1997. Lietuvos Kataliku Bažnyčia ir tautybė XIX amžiuje. In Krikščionybė Lietuvoje. Edited by Vytautas S. Vardys. Čikaga: Lietuvos Krikščionybės Jubiliejaus Komitetas, pp. 216-39.

Vardys, Vytautas S., and Judith B. Sedaitis. 1997. Lithuania: The Rebel Nation. Boulder: Westview Press.

Žiliukaitè, Rūta, Arūnas Poviliūnas, and Aida Savicka. 2016. Lietuvos Visuomenès Vertybiu Kaita per Dvidešimt Nepriklausomybės Metu. Vilnius: Vilniaus Universiteto Leidykla. 